\title{
Ecological and morphological characteristics of Steinernema kraussei (Rhabditida: Steinernematidae): comparison of nematodes isolated from the natural environments and originated from the commercial pesticide
}

\author{
Joanna Matuska-Łyżwa \\ The Jan Kochanowski University in Kielce, Faculty of Mathematics and Natural Sciences, Institute of Biology, \\ Department of Zoology and Biological Didactics, Świętokrzyska 15, 25-406 Kielce, Poland, \\ e-mail: joannaujk@op.pl
}

\begin{abstract}
Biological activity and morphometric characteristics of entomopathogenic nematodes, Steinernema kraussei, isolated from the Świętokrzyski National Park were studied. The results have shown that $S$. kraussei has slower, but more efficient invasiveness than nematodes originated from the bio-pesticide. Morphometric comparative analysis did not show any significant differences between nematodes isolated from natural environment and those from control sample. It was also shown that the reproduction rate of isolates collected from the soil was $45 \%$ higher than the reproduction rate of nematodes originated from the commercial pesticide.
\end{abstract}

Key words: entomopathogenic nematodes, Steinernematidae Steinernema kraussei, Nemasys L.

\section{Introduction}

The biodiversity of species present in the environment has a profound impact on the behavior of local, often rare organisms. The changes that occur in the ecosystems caused by anthropogenic factors may have adverse effect on the genetic diversity of the population and result in immunodepression to illnesses or to pests. As in many groups of other organisms, there are also rare or not observed so far species among entomopathogenic nematodes (Sienkiewicz 2010).

Entomopathogenic nematodes are widely distributed in soil throughout all the world (Hominick et al. 1996). They are highly pathogenic to insects when they are in symbiosis with bacteria from Photorhabdus and Xenorhabdus genera (Boemare et al. 1997; Adams et al. 2006). They are able to actively search and infect the host organism. Such nematodes are characterized by high reproduction rate, as well as the ease of highly effective mass-production. Usually they are harmless to plants and vertebrates what makes them a perfect source for preparing of bio-pesticides (Kaya \& Gaugler 1993; Burnell \& Stock 2000; Ehlers 2001).

New habitats and species of nematodes are still discovered in the world (Özer et al. 1995; Stock 1995; Gwynn \& Richardson 1996; Constant et al. 1998; Miduturi et al. 1996; Griffin et al. 2000; Hazir et al. 2003; Tóth 2006).

In Poland seven species of entomopathogenic nematodes have been identified so far: Steinernema feltiae [Filipjev] (Sandner \& Bednarek 1987; Bednarek 1990; Dzięgielewska 2001; Matuska 2008), S. carpocapsae [Weiser] (Bednarek 1990; Matuska 2008), S. bicornutum [Tallosi, Peters \& Ehlers] (Dzięgielewska 2001), S. affine [Bovien] (Matuska 2008), S. intermedium [Poinar] (Matuska 2008), Heterorhabditis bacteriophora [Poinar] (Matuska 2008), H. megidis [Poinar, Jackson \& Klein] (Dzięgielewska 2001; Matuska 2008). The most common of them is S. feltiae (Matuska 2008). 
S. kraussei is also fairly common species. It was found in: the Czech Republic, Germany, Great Britain, the Netherlands, Spain, South America and Iceland (Mráček 1980; 1994; Hominick et al. 1995; 1996; Garcia del Pino \& Palomo 1996; Steiner 1996; Mráček et al. 1999; Stock et al. 1999; Spiridonov et al. 2004).

The species has not been previously observed in Poland. This work describes the presence of $S$. krausseri in Poland, as well as some ecological and morphometric features of nematodes found.

\section{Materials and methods}

Larvae of nematodes where isolated from the soil sample of alluvial forests in the area of the Klonowskie Mountain Range in the Świetokrzyski National Park. Fifty representative soil samples were collected from the examined areas using Egner's stick device to a depth of $25 \mathrm{~cm}$. Thereafter, nematodes were isolated by the method of Bedding and Akhurst (1975) in a laboratory environment. Soil samples were mixed carefully and placed into six sterile polypropylene containers with a capacity of $250 \mathrm{~cm}^{3}$. Two larvae of the test insect were added (the last larval stage of Galleria mellonella $\mathrm{L}$.) to each container. This control process of soil sampling was carried out every 48 hours for 16 days. The dead insect larvae were placed on a migratory sponge in a Petri dish and incubated at $20^{\circ} \mathrm{C}$. The dead larvae from the samples were replaced with new larvae. When the first migrating nematodes were spotted on the dish, only then began the collection of larvae into the bottles used for tissue culture. Decantation of nematodes was carried out for 10 days and kept refrigerated at $4-5^{\circ} \mathrm{C}$.

Nematodes isolated from the soil samples were subject to the molecular analysis sequencing reaction of the PCR product with complementary primers to genes coding for ribosomal RNA S. kraussei (Nguyen \& Hunt 2007).

Infective juvenile and the first generation of individuals was used for morphometric analysis due to possessing the largest number of characteristics of the species under research (Hominick et al. 1997, Stock et al. 2000). The nematodes' body length, its width, the length of its pharynx, the length of its tail and additionally the length of spicules in male individuals were measured.

In order to evaluate the invasiveness, the test insects were infected with a dose of 50 larvae of nematodes per one insect and the following aspects were tested: the mortality of insects, the time-length of causing death of the host, the extensiveness and intensiveness of invasion, and their ability to reproduce. The control sample consisted of the nematodes originated from the commercial pesticide Nemasys L based on the S. kraussei and used for control of black vine weevil (Otiorhynchus sulcatus) - a pest at tree nurseries, garden plants and fruit.

For statistical analysis One-Way ANOVA has been used.

\section{Results and discussion}

The results of molecular analysis have shown that the collected isolate belongs to $S$. kraussei.

By evaluating biological activity it was found that nematodes isolated from the natural environment possess slower, however, more efficient invasiveness than nematodes originated from the bio-pesticide. Nematodes isolated from the ground caused death of the insects one day later than nematodes from the control sample, as well as they began later to migrate from insect cavity to the external environment (Table 1).

Table 1. The biological activity of $S$. kraussei

\begin{tabular}{|c|c|c|}
\hline Tested samples & $\begin{array}{c}\text { Control } \\
\text { sample }\end{array}$ & $\begin{array}{c}\text { S. kraussei } \\
\text { isolated from } \\
\text { the natural } \\
\text { environment }\end{array}$ \\
\hline Total mortality of insects [\%] & 100 & 100 \\
\hline Extensiveness of invasion [\%] & 98 & 97 \\
\hline Intensity of invasion (mean) [ind.] & $6^{1}$ & $8^{1}$ \\
\hline Intensity of invasion (minimum) [ind.] & 2 & 4 \\
\hline $\begin{array}{c}\text { Intensity of invasion (maximum) } \\
\text { [ind.] }\end{array}$ & 13 & 14 \\
\hline $\begin{array}{c}\text { Time to kill the insect by the } \\
\text { nematodes [days] }\end{array}$ & 3 & 4 \\
\hline $\begin{array}{c}\text { The migration first day of invasive } \\
\text { larvae from the insect-host to the } \\
\text { external environment [days] }\end{array}$ & $10^{2}$ & $13^{2}$ \\
\hline $\begin{array}{c}\text { Mean number of migrating larvae } \\
\text { from an insect [ind.] }\end{array}$ & $12,483^{3}$ & $22,537^{3}$ \\
\hline
\end{tabular}

ind. - individuals

Indexes ${ }^{1,2,3}$ indicate statistically significant differences $(\mathrm{p}<0.05)$ between data in both columns

Insects' mortality and extensiveness of invasion was similar in both analyzed tests. The differences, however, were observed in intensiveness of invasion. Nematodes isolated from the natural environment had higher intensity of invasion than nematodes from the control sample, both in the lowest and the highest numbers of nematodes identified during an autopsy of the insects. The results of other authors show similar results. It was proven that the local populations of nematodes show higher biological activity in relation to the host than the isolates originating from a different region (Mráček et al. 1998). It can be assumed that nematodes adapt to the particular environment and occurring changes during the season make them more resistant and they show higher invasiveness than nematodes taken from other sources. 
Table 2. Morphometric parameters of S. kraussei $[\mu \mathrm{m}]$

\begin{tabular}{|c|c|c|c|c|c|c|c|c|c|}
\hline \multirow[b]{2}{*}{$\begin{array}{l}\text { Analysed } \\
\text { body sizes }\end{array}$} & \multicolumn{3}{|c|}{ Infective juvenile } & \multicolumn{3}{|c|}{ First generation female } & \multicolumn{3}{|c|}{ First generation male } \\
\hline & $\begin{array}{l}\text { Control } \\
\text { sample }\end{array}$ & $\begin{array}{c}\text { S. kraussei } \\
\text { isolated } \\
\text { from the } \\
\text { natural } \\
\text { environment }\end{array}$ & $\begin{array}{l}\text { Range } \\
\text { for the } \\
\text { species } \\
\text { [Mráček } \\
\text { 1994] }\end{array}$ & $\begin{array}{l}\text { Control } \\
\text { sample }\end{array}$ & $\begin{array}{c}\text { S. kraussei } \\
\text { isolated from } \\
\text { the natural } \\
\text { environment }\end{array}$ & $\begin{array}{l}\text { Range } \\
\text { for the } \\
\text { species } \\
\text { [Mráček } \\
\text { 1994] }\end{array}$ & $\begin{array}{l}\text { Control } \\
\text { sample }\end{array}$ & $\begin{array}{c}\text { S. kraussei } \\
\text { isolated from } \\
\text { the natural } \\
\text { environment }\end{array}$ & $\begin{array}{l}\text { Range for } \\
\text { the species } \\
\text { [Mráček } \\
1994]\end{array}$ \\
\hline \multirow{2}{*}{$\begin{array}{c}\text { Body } \\
\text { length }[\mu \mathrm{m}]\end{array}$} & $910.8^{1}$ & $937.7^{1}$ & 951 & $4,929.17$ & $5,009.3$ & 4,200 & $1,417.5$ & $1,444.6$ & 1,400 \\
\hline & $797-1,100$ & $798-1,100$ & $797-1,102$ & $\begin{array}{c}3,750- \\
5,400\end{array}$ & $4,300-5,400$ & $\begin{array}{c}2,500- \\
5,400\end{array}$ & $\begin{array}{c}1,200- \\
1,570\end{array}$ & $1,200-1,610$ & $\begin{array}{l}1,200- \\
1,600\end{array}$ \\
\hline \multirow{2}{*}{$\begin{array}{l}\text { Body width } \\
\quad[\mu \mathrm{m}]\end{array}$} & 32.1 & 32.4 & 33 & $219.03^{2}$ & $233.97^{2}$ & 240 & $123.53^{3}$ & $130.53^{3}$ & 128 \\
\hline & $29-36$ & $30-36$ & $30-36$ & $158-260$ & $158-286$ & $153-288$ & $110-140$ & $110-142$ & $110-144$ \\
\hline \multirow{2}{*}{$\begin{array}{c}\text { Length of } \\
\text { the pharynx } \\
{[\mu \mathrm{m}]}\end{array}$} & 129 & 131 & 134 & 190.8 & 192.13 & 192 & $147.83^{4}$ & $157.57^{4}$ & 153 \\
\hline & $120-144$ & $122-145$ & $119-145$ & $178-200$ & $182-203$ & $178-205$ & $135-170$ & $138-175$ & $139-178$ \\
\hline \multirow{2}{*}{$\begin{array}{l}\text { Tail length } \\
{[\mu \mathrm{m}]}\end{array}$} & 74 & 75 & 79 & 49.53 & 49.87 & 48 & $39.73^{5}$ & $37.87^{5}$ & 39 \\
\hline & $72-87$ & $73-87$ & $69-86$ & $34-59$ & $38-56$ & $33-59$ & $37-44$ & $36-42$ & $36-44$ \\
\hline \multirow{2}{*}{$\begin{array}{l}\text { Length of } \\
\text { spicule } \\
{[\mu \mathrm{m}]}\end{array}$} & - & - & - & - & - & - & 48.47 & 48.03 & 49 \\
\hline & - & - & - & - & - & - & $42-53$ & $43-53$ & $42-53$ \\
\hline
\end{tabular}

Indexes ${ }^{1-5}$ indicate statistically significant differences $(\mathrm{p}<0.05)$ between data in both columns

Extremely noticeable differences were observed between the tested samples during assessing reproduction of nematodes. The amount of migrating larvae of strain isolated from the ground was $45 \%$ higher than nematodes originated from the bio-pesticide. The obtained results allow to assume that the organisms isolated from the natural environment are better adapted to local environment than nematodes from the commercial product applied to pest control.

Statistical analysis (One-Way ANOVA) have shown significant differences in "intensiveness of invasion" and highly fundamental differences in "the number of migrating larvae from the insect" between the control sample and nematodes isolated from the natural environment. The differences between the samples in the number of migrating larvae from the insects confirmed the results obtained by other researchers who proved that the number of nematodes may vary from a few thousands to a few hundred thousand (Mason \& Hominick 1995; Strong et al. 1996). The differences in biology of nematodes isolated from the natural environment were also shown by other researchers of S. kraussei isolates originated from the Czech Republic and Canada (Mráček et al. 1998).

By analyzing the morphometric parameters of nematodes isolated from the soil and nematodes from the bio-pesticide, it was proved that both samples are consis- tent with the standard sizes of species given in the references (Mráček 1994) and there are no significant differences between them (Table 2, Fig. 1).

Similar analyses were conducted by Nikdel et al. (2011). They also show that the morphological features of $S$. kraussei isolates collected from the natural environment are compatible with typical species (Mráček 1994). Nematodes larvae isolated in Iran, comparing to the size of Polish $S$. kraussei isolates, seems to be shorter and wider. Additionally, Polish isolates have longer pharynx and shorter tail than invasive larvae from Iran. For the male from the first generation most of examined parameters (without the body length and the length of spicule) were higher than the sizes of nematodes from Iran.

Conducting researches on the effectiveness of nematodes originated from the natural environments against the plant pests is one of the most recent fields of research in Europe (Mráček et al. 1998; Lakatos \& Tóth 2006).

Awareness of species diversity and detailed characteristics of entomopathogenic nematodes may provide a significant assistance in studying of bioinsecticides that will be better adjusted to particular conditions of the environment. 


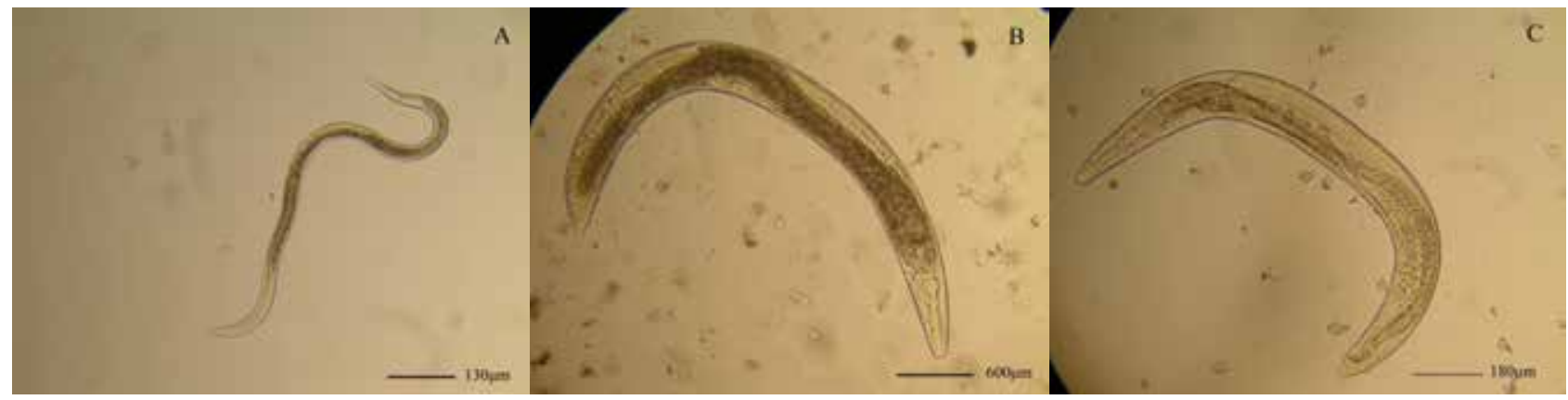

Figure 1. Steinernema kraussei (A - infective juvenile, B - first generation female, C - First generation male (Fot. J. Matuska-Łyżwa in 2012)

\section{References}

Adams B. J., Fodor A., Koppenhofer H. S., Stackebrandt E., Stock S. P. \& Klein M. G., 2006, Biodiversity and systematics of nematode-bacterium entomopathogens, Biological Control: Theory and Applications in Pest Management 37(1): 32-49, DOI:10.1016/j.biocontrol.2005.11.008.

Bedding R. A. \& Akhurst R. J., 1975, A simple technique for the detection of insect parasitic rhabditid nematodes in soil, Nematologica 21: 109-110.

Bednarek A., 1990, Ekologiczne uwarunkowania aktywności biologicznej nicieni entomofilnych w środowisku glebowym agrocenoz, Rozprawy naukowe i Monografie [Ecological determinants of biological activity of entomophilous nematodes in the soil environment of agrocenoses, Scientific Theses and Monographs], Wyd. SGGW, Warszawa.

Boemare N. E., Givandan A., Brehelin M. \& Laumond C., 1997, Symbiosis and pathogenicity of nematode-bacterium complexes, Symbiosis 22: 21-45.

Burnell A. M. \& Stock S. P., 2000, Heterorhabdits, Steinernema and their bacterial symbionts - lethal pathogens of insect, Nematology 2: 31-42.

Constant P., Marchay L., Fischer-Le Saux M., Briand-Panoma S. \& Mauleon H., 1998, Natural occurrence of entomopathogenic nematodes (Rhabditida: Steinernematidae and Heterorhabditidae) in Guadeloupe islands, Fundamental and Applied Nematology 21: 667-672.

Dzięgielewska M., 2001, Występowanie nicieni owadobójczych (Steinernematidae, Heterorhabditidae) w północno-zachodniej Polsce oraz biologia i zdolności infekcyjne Steinernema bicornutum (Tallosi, Peters $\&$ Ehlers), Praca dokt. [The occurrence of insecticidal nematodes (Steinernematidae, Heterorhabditidae) in north-western Poland, biology and infectious ability of Steinernema bicornutum (Tallosi, Peters \& Ehlers), Ph.D. Thesis], Akademia Rolnicza, Szczecin.
Ehlers R. U., 2001, Mass production of entomopathogenic nematodes for plant protection, Applied Microbiology and Biotechnology 56(5-6): 623-633.

Garcia Del Pino F. \& Palomo A., 1996, Natural occurrence entomopathogenic nematodes (Rhabditida: Steinernematidae and Heterorhabditidae) in Spanish soils, Journal of Invertebrate Pathology 68: 84-90.

Griffin C. T., Chaerani R., Fallon D., Reid A. P. \& Downes M. J., 2000, Occurrence and distribution of the entomopathogenic nematodes Steinernema spp. and Heterorhabditis indica in Indonesia, Journal of Helminthology 74(2): 143-150.

Gwynn R. L. \& Richardson P. N., 1996, Incidence of entomopathogenic nematodes in soil samples collected from Scotland, England and Wales, Fundamental and Applied Nematology 19: 427-431.

Hazir S., Keskin N., Stock S. P., Kaya H. K. \& Özcan S., 2003, Diversity and distribution of entomopathogenic nematodes (Rhabditida: Steinernematidae and Heterorhabditidae) in Turkey, Biodiversity and Conservation 12(2): 375-386.

Hominick W. M., Reid A. P. \& Briscoe B. R., 1995, Prevalence and habitat specificity of steinernematid and heterorhabditid nematodes isolated during surveys of the UK and the Netherlands, Journal of Helminthology 69: 27-32.

Hominick W. M., Reid A. P., Bohan D. A. \& Briscoe B. R., 1996, Entomopathogenic nematodes-biodiversity, geographical distribution and the convention on biological diversity, Biocontrol Science and Technology, 6(3): 317-332, DOI: 10.1080/09583159631307.

Hominick W. M., Briscoe B. R., Garcia del Pino F. G., Heng J., Hunt D. J., Kozodoy E., Macrek Z., Nguyen K. B., Reid A. P., Spiridonov S., Stock P., Sturhan D., Waturu C. \& Yoshida M., 1997, Biosystematics of entomopathogenic nematodes: current status, protocols and definitions, Journal of Helminthology 71: 271-298.

Kaya H. K. \& Gaugler R., 1993, Entomopathogenic nematodes. Annual Review of Entomology 38: 181-206. 
Lakatos T. \& Tóth T., 2006, Biological control of european cockchafer larvae (Melolontha melolontha L.): Preliminary results, Journal of Fruit and Ornamental Plant Research 14(3): 73-78.

Mason J. M. \& Hominick W. M., 1995, The effect of temperature on infection, development, and reproduction of Heterorhabditids, Journal of Helminthology 69(4): 337-345, DOI: 10.1017/S0022149X00014929.

Matuska J., 2008, Wpływ czynników biotycznych i abiotycznych na nicienie entomopatogeniczne, Praca dokt. [The influence of biotic and abiotic factors on entomopathogenic nematodes, Ph.D. Thesis], SGGW, Warszawa.

Miduturi J. S., Moens M., Hominick W. M., Briscow B. R. \& Reid A. P., 1996, Naturally occurring entomopathogenic nematodes in the province of West-Flanders, Belgium, J. Helminth. 70: 319 - 327, DOI: 10.1017/ S0022149X00015613.

Mráček Z., 1980, The use of 'Galleria traps' for obtaining nematode parasites of insects in Czechoslovakia (Lepidoptera: Nematoda, Steinernematidae), Acta Entomologica Bohemoslovaca 77(6): 378-382.

Mraček Z., 1994, Steinernema kraussei (Steiner, 1923) (Nematoda: Rhabditida: Steinernematidae): redescription of its topotype from Westphalia, Folia Parasitologica 41: 59-64.

Mráček Z., Bečvář S. \& Kindlmann P., 1999, Survey of entomopathogenic nematodes from the families Steinernematidae and Heterorhabditidae (Nematoda: Rhabditida) in the Czech Republic, Folia Parasitologica 46: 145-148.

Mráček Z., Bečvář S., Kindlmann P. \& Webster J., 1998, Infectivity and specificity of Canadian and Czech isolates of Steinernema kraussei (Steiner, 1923) to some insect pests at low temperatures in the laboratory, Nematologica 44: 437-448, DOI: 10.1163/005525998X00098.

Nguyen K. B. \& Hunt D. J., 2007, Entomopathogenic Nematodes: Systematics, Phylogeny and Bacterial Symbionts, Brill. Leiden-Boston 5: 63-67.

Nikdel M., Niknam G. \& Eivazian Kary N., 2011, First report of an entomopathogenic nematode, Steinernema kraussei (Rhabditida, Steinernematidae) from Iran, Journal of Entomological Society of Iran 30(2): 39-51.
Özer N., Keskin N. \& Kirbas Z., 1995, Occurrence of entomopathogenic nematodes (Steinernematidae: Heterorhabditidae) in Turkey, Nematologica 5(41): 693640.

Sandner H. \& Bednarek A., 1987, Nicienie entomofilne Świętokrzyskiego Parku Narodowego [Entomophilic nematodes of the Świętokrzyski National Park], Fragmenta Faunistica 31(1): 3-9.

Sienkiewicz J., 2010, Koncepcje bioróżnorodności - ich wymiary i miary w świetle literatury [Concepts of biodiversity - their dimensions and measures in the light of literature], Ochrona Środowiska i Zasobów Naturalnych 45: 7-29.

Spiridonov S., Lyons E. \& Wilson M., 2004, Steinernema kraussei (Rhabditida, Steinernematidae) from Iceland, Comparative Parasitology 71(2): 215-220.

Steiner A., 1996, Distribution of entomopathogenic nematodes in the Swiss Alps, Revue Suisse de Zoologie 103: 439-452.

Stock S. P., 1995, Natural populations of entomopathogenic nematodes in the Pampean region of Argentina, Nematropica 2(25): 143-148.

Stock S. P., Pryor B. M. \& Kaya H. K., 1999, Distribution of entomopathogenic nematodes (Steinernematidae and Heterorhabditidae) in natural habitats in California, USA, Biodivision Conservation 8: 535-549.

Stock S. P., Mrácek Z. \& Webster M., 2000, Morphological variation between allopatric populations of Steinernema krausei (Steiner, 1923) (Rhabditida: Steinernematidae), Nematology 2: 143-152.

Strong D. R., Kaya H. K., Whipple A. V., Child A. L., Kraig S., Bondonno M., Dyer K. \& Maron J. L., 1996, Entomopathogenic nematodes: Natural enemies of root-feeding caterpillars on bush lupine. Oecologia 108(1): 167-173, DOI:10.1007/BF00333228.

Tóth T., 2006, Collection of entomopathogenic nematodes for biological control of insect pests, Journal of Fruit and Ornamental Plant Research 14(3): 225-230. 